\title{
QUORUM-SENSING NETWORK-ASSOCIATED GENE REGULATION IN GRAM-POSITIVE BACTERIA
}

\author{
GOUTAM BANERJEE* and ARUN KUMAR RAY \\ Department of Zoology, Visva-Bharati University, Santiniketan, West Bengal, India
}

(Received: 20 April 2016; revised manuscript received: 26 October 2016; accepted: 8 August 2017)

Quorum sensing (QS) is the chemical communication processes between bacteria, which may be inter-genus or intra-genus. In general, several physiological functions, such as nutrient uptake, competence development, biofilm formation, sporulation, and toxin secretion, are accomplished through QS process. The QS (cell density-dependent process) circuit in Gram-positive bacteria consists mainly of two parts: an inducer molecule and a receptor protein. The binding of inducer molecule to receptor activates the target gene, which then performs the necessary function in bacteria. In the past few years, several investigations have been conducted to explore the QS circuit in various bacteria, but still this information is insufficient to fully understand the bacterial gene expression cascade. In the present review, we summarize the QS architecture and their associated gene regulation in four Gram-positive bacteria, such as Bacillus subtilis, Staphylococcus aureus, Bacillus cereus, and Streptococcus pneumoniae. It is well established that $S$. aureus, B. cereus, and $S$. pneumoniae are potent human pathogen. A detailed understanding of QS circuit in these bacteria would be useful in preparation of customized medicine in future. Whereas, $B$. subtilis is an industrially important candidate and has been used in several biotechnology sectors. Understanding of QS circuit in B. subtilis will definitely enrich the antibiotics and enzyme industries.

Keywords: Gram-positive bacteria, quorum-sensing circuit, gene expression, pathogenicity

\section{Introduction}

The chemical communication or quorum sensing (QS) is a sequential process initiated by binding of an extracellular signal to a receptor. It is a critical cascade pathway in bacteria, which is not only important for survival in

\footnotetext{
*Corresponding author; E-mail: banerjee.goutam2@gmail.com
} 
competitive environment but also significant in maintaining normal cell physiology, cell growth, and nutrient uptake. In 1984, Engebrecht and Silverman [1] had investigated the light production phenomenon in detail and had stated that the activation of luciferase gene is responsible for light production in bacteria. Later on, Nealson and Hastings [2] first described the QS mechanism and its associated gene regulation in two luminous bacterial strains, Vibrio fischeri and Vibrio harveyi. Furthermore, their results also demonstrated that QS is a cell density-dependent process and the activation of QS-associated genes is dependent on the threshold value of the stimulating molecules. The QS process is common in both Gram-negative bacteria and Gram-positive bacteria, although it differs greatly in terms of inducer molecules, response circuit, and mechanism. In general, Gram-negative bacteria produce a small signaling molecule called acyl homoserine lactone (AHL), which after reaching the threshold concentration enter the cell, bind to regulatory protein, which then act as a transcription factor for several enzymes and virulence factor secretion genes [3, 4]. On the other hand, in Grampositive bacteria, a precursor oligonucleotide molecule is cleaved into a functional signaling molecule (10-20 amino acids), transported outside the cell by a special channel protein and after reaching the threshold concentration, it binds to a receptor protein on the surface of the cell. The binding of the signaling molecule phosphorylates the receptor molecule, which transfers its phosphate $(\mathrm{P})$ to a response regulatory protein, which then binds to a specific site in the DNA and activates several QS-associated genes [5]. In a recent review, Deep et al. [6] have stated that a significant portion of the proteome $(\geq 20 \%)$ and the bacterial genome $(4 \%-10 \%)$ are influenced by QS signaling processes. Furthermore, synchronization of virulence factor-associated gene expression in pathogenic bacteria is very important and controlled by QS process $[4,7,8]$. Besides regulating pathogenicity, QS-mediated gene expression also plays a critical role in bacterial metabolism [9]. Furthermore, researchers also stated that bacteria use QS network to control a wide range of function, such as sporulation, competence development, motility, biofilm formation, antibiotic production, and conjugation [10-12].

Research on QS mechanism in Gram-negative bacteria is very common, as most of the pathogenic bacteria belong to the Gram-negative group and their pathogenic efficiency is highly regulated by a QS process $[8,13]$. On the other hand, reports on QS-mediated gene expression in Gram-positive bacteria are scanty. Therefore, an emphasis has been given to summarize the available information of QS-associated gene regulation in Gram-positive bacteria. Although the QS system in Gram-positive bacteria is also diverse, we have picked four species: Bacillus subtilis, Staphylococcus aureus, Bacillus cereus, and Streptococcus pneumoniae. We have critically analyzed the QS system in these four species, because $S$. aureus, B. cereus, and S. pneumoniae are considered to be 
potent human pathogen, and $B$. subtilis is recognized as an industrially important (antibiotics and enzyme industry) candidate.

\section{QS in Gram-positive bacteria}

QS-mediated gene expression in response to cell density is a common phenomenon in bacteria. In the past few years, the QS-associated response in Gram-positive bacteria has extensively been investigated (Table I). In Grampositive bacteria, the induction pathway is a two-component system, which contains an inducer molecule and a kinase receptor in the membrane [8]. The phosphorylation of the receptor kinase activates the regulatory protein, which acts as transcription factor of the QS target gene. Jimenez and Federle [23] reported the occurrence of two families of transcription factors, RNPP and Rgg, which possess pheromone-binding domain. RNPP is recognized as a critical factor in regulation of several processes like sporulation, conjugation, biofilm formation, and pathogenic responses [24]. In case of Gram-positive bacteria, the population density is directly proportional to the amount of secreted peptides (10). Signaling molecules used in Gram-positive bacteria are either unmodified or posttranslationally modified small peptides, secreted via ABC exporter proteins [25]. Furthermore,

Table I. Quorum-sensing-associated phenotype in Gram-positive bacteria

\begin{tabular}{|c|c|c|c|}
\hline Bacteria & Signal & Phenotype & References \\
\hline $\begin{array}{l}\text { Lactobacillus } \\
\text { lactis }\end{array}$ & Modified nisin & Nisin-like bacteriocin & {$[14]$} \\
\hline Bacillus subtilis & ComX-pheromone, CSF & $\begin{array}{l}\text { Competence, sporulation, and } \\
\text { biofilm formation }\end{array}$ & [11] \\
\hline $\begin{array}{l}\text { Clostridium } \\
\text { difficile }\end{array}$ & $4 \mathrm{OH}-5$-methyl-3(2)-H furanone & Toxin production & {$[15]$} \\
\hline $\begin{array}{l}\text { Listeria } \\
\quad \text { monocytogenes }\end{array}$ & AIP & Virulence & [16] \\
\hline $\begin{array}{l}\text { Streptococcus } \\
\text { mutans }\end{array}$ & CSP, XIP & Competence and virulence & [12] \\
\hline Streptomyces sp. & $\begin{array}{l}\gamma \text {-butyrolact - one, PI and } \\
\text { M-factors }\end{array}$ & Antibiotics production & {$[17]$} \\
\hline $\begin{array}{l}\text { Enterococcus } \\
\text { faecalis }\end{array}$ & $\begin{array}{l}\text { Gelatinase biosynthesis- } \\
\text { activating pheromone }\end{array}$ & $\begin{array}{l}\text { Virulence and protease } \\
\text { production }\end{array}$ & [18] \\
\hline $\begin{array}{l}\text { Lactobacillus } \\
\text { plantarum }\end{array}$ & PLNC8IF & $\begin{array}{l}\text { Plantaricin-like bacteriocin } \\
\text { production }\end{array}$ & {$[19,20]$} \\
\hline $\begin{array}{l}\text { Streptomyces } \\
\text { griseus }\end{array}$ & $\gamma$-butyrolactone & Secondary metabolites & {$[21,22]$} \\
\hline
\end{tabular}

Note: CSP: competence stimulating peptide; XIP: sigx inducing peptide; CSF: competence stimulating factor; AIP: autoinducing peptide. 
several researchers have reported that the active peptides are formed from a larger precursor protein and then modified by adding several chemical groups like thiolactone ring, lactone, isoprenyl, etc. [18, 26, 27]. It is now well-established that the bacteria produce signaling peptides continuously throughout their population growth, but the QS pathway is getting activated only at a high cell density [6, 8]. Whereas, Bendori et al. [28] have reported the activation of RapP-PhrP QS system in B. subtilis occurs at low cell density. In the following, we will discuss few interesting QS phenomena in bacteria belonging to the Gram-positive group.

\section{QS circuit in B. subtilis}

B. subtilis is rod shaped, catalase positive, endospore forming bacterium most distributed in soil and gut of animals. The competency property of this bacterial species is dependent on the QS gene regulation. In an investigation Grossman [29] stated that $B$. subtilis becomes competent at the transition between logarithmic and stationary growth phase. Zafra et al. [30] characterized an extracellular DNA-based regulation in B. subtilis at late exponential phase, which was related to an early competence signaling pathway. The protein associated with competence property was tightly regulated by QS system involved in ComPComA system and ComX pheromone [31-34]. In the presence of ComX, the histidine kinase ComP activates ComA, which acts as regulatory factor for QS genes [35]. The activated QS system then expresses the competence transcription factor ComK and resulting in DNA uptake [36]. The detail mechanism is illustrated in Figure 1. Sporulation is another classical example of QS-mediated response in B. subtilis. In adverse environmental conditions, B. subtilis forms endospore for survival. The competence stimulating factor (CSF) is a pentapeptide and has a binding domain on a ComA-specific phosphatase, RapC. At lower concentration, CSF binds with RapC and promotes competence, whereas at higher concentration, CSF inhibits the CosS gene and promotes the degradation of ComK protein and thus promotes sporulation (Figure 1) [34-36]. In a recent study, Dogsa et al. [34] investigated the presence of Com QXPA locus in several other bacterial species. Their results demonstrated the presence of Com QXPA system in a variety of bacterial species, but interestingly all of these belong to the phylum Firmicutes. Detailed research should be conducted to explore the relationship between the Com QXPA system and bacterial molecular evolution.

Virulence factor-associated QS in S. aureus

S. aureus is an invasive human pathogen, which causes several diseases, such as food poisoning, skin infection, endocarditis, and pneumonia [37]. Due to 


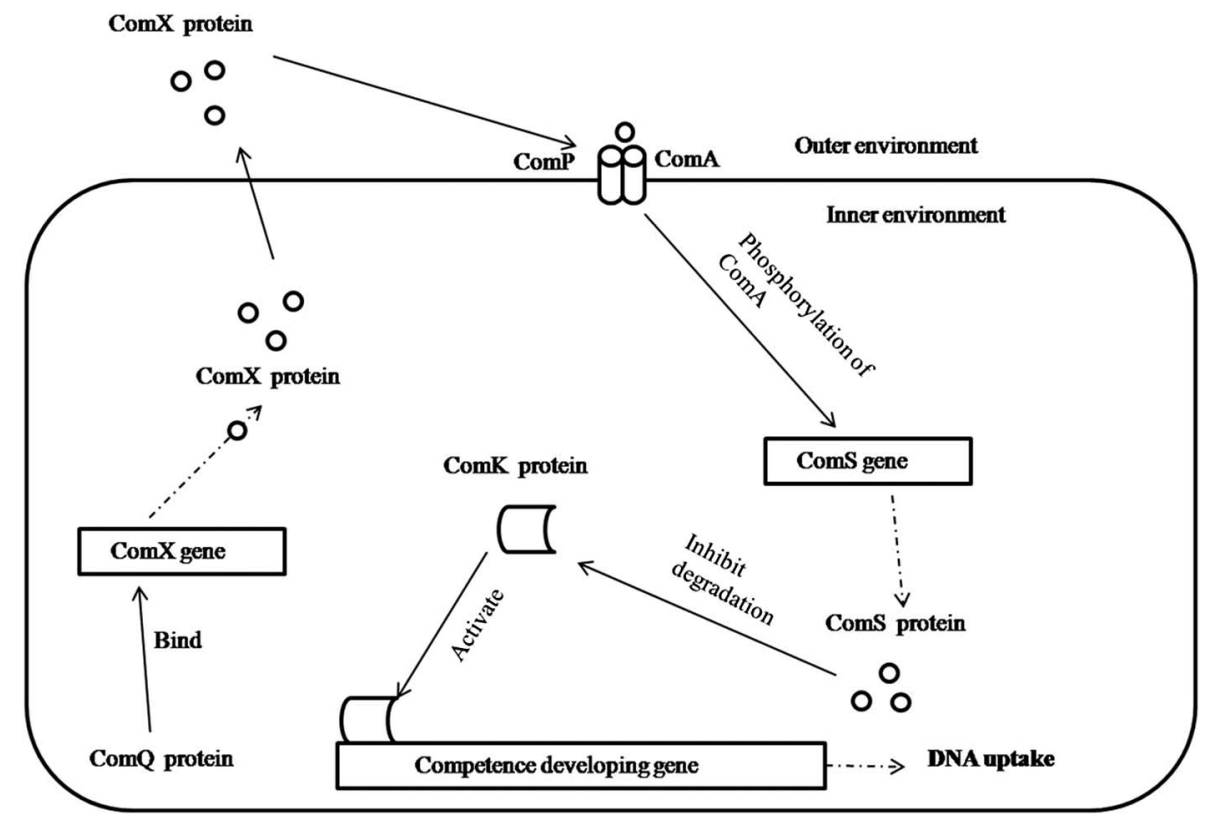

Figure 1. Quorum-sensing-associated gene regulation in Bacillus subtilis showing competence development. ComX protein acts as a signaling molecule, which activates the membrane-bound ComP-ComA system. Upon activation, the ComP-ComA system phosphorylates ComS gene and produces ComS protein, which is responsible for maintaining the stability of ComK protein and ultimately switching on the competence development gene cascade. Square boxes, curved boxes, solid, and dashed dotted lines indicate the genes, protein, direction of signaling pathway, and the products of the expressed genes, respectively. Small round circle indicates signaling molecules

the antibiotic-resistant property of the bacteria, the infection caused by S. aureus is difficult to treat [38]. The degree of pathogenicity exhibited by $S$. aureus depends on its successful invasion inside the tissue, and this process is a QS-associated phenomenon [39]. The accessory gene regulator (agr) system comprises two RNA transcripts, RNA II and RNAIII [10, 40]. The RNAII operon system consists of four genes, $\operatorname{agr} B, \operatorname{agr} D, \operatorname{agr} C$, and $\operatorname{agr} A$. The signaling cascade begins with the production of a 46 amino acid peptide encoded by $\operatorname{agr} D$ gene, which is then modified by an integral membrane protein AgrB [41, 42]. The modified octapeptide acts as a final autoinducing peptide (AIP) that contains a thiolactone ring, which is required for signaling activity. The AgrA and AgrC together form the two-component system that has the binding domain of AIP and act as a histidine kinase [40]. The induction of two-component system activates the RNAII operon, as well as acts as transcription factor for RNAIII transcript itself. Activation of RNAIII produces several virulence factors, such as hemolysin, Protein A, 


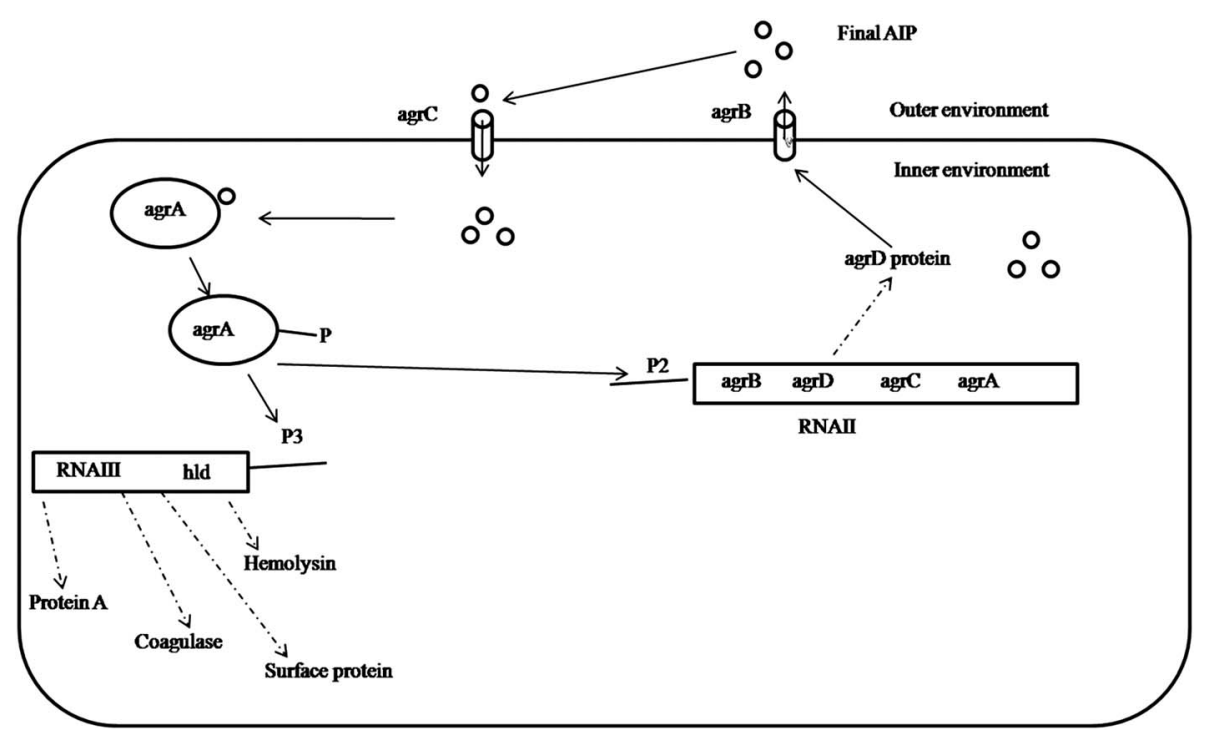

Figure 2. Quorum sensing regulated virulence factors secretion in Staphylococcus aureus. The agr operon initiates the virulence factor secretion pathway through the production of AgrD protein, which activates the cell membrane-bound AgrB. The activated AgrB produces the signaling molecule AIP, which again internalizes through with the AgrC channel protein, binds to AgrA protein, and stimulates the expression of RNAIII transcript for the production of virulence factors. Square boxes, round boxes, solid, and dashed dotted lines indicate the genes, protein, direction of signaling pathway, and the products of the expressed genes, respectively. Small round circle indicates signaling molecules

coagulase, and surface protein (Figure 2). Queck et al. [43] have also reported the expression of phenol-soluble gene by phosphorylated agrA. Biofilm development is another important phenomenon exhibited by $S$. aureus [43]. Several researchers suggested that the agr system actively inhibits biofilm formation in S. aureus and this might be a strategy to facilitate the dispersal $[44,45]$. The virulence factors secretion by $S$. aureus is an iron-dependent process. In a detail study, Oogai et al. [46] reported that expression of different virulence factors, including RNAIII transcript, was much higher in $S$. aureus grown in calf serum compared with normal medium. The better understanding of QS network in drug-resistant $S$. aureus might be useful in treating lung disease.

\section{Expression of virulence factors in B. cereus}

B. cereus is a Gram-positive pathogenic bacterium, which is able to colonize the intestine and cause human disease, such as diarrhea, as well as produce several 


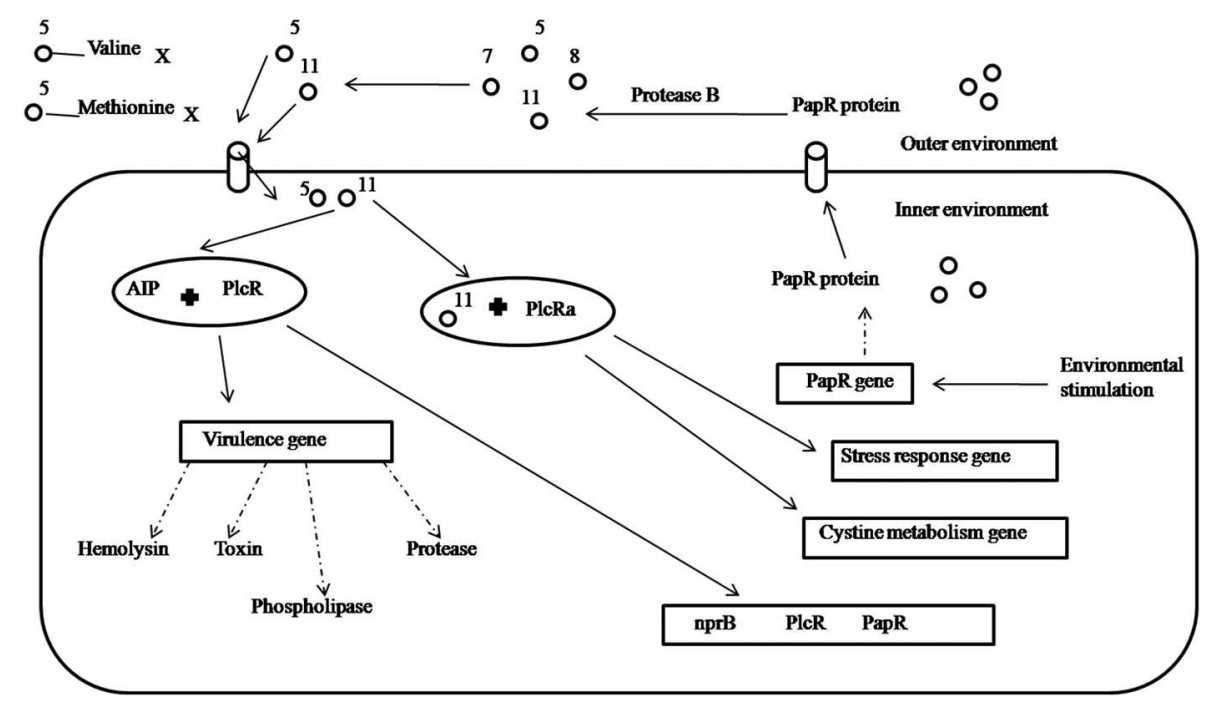

Figure 3. The illustration demonstrates the quorum-sensing circuit in Bacillus cereus. Upon environmental stimulation, the PapR gene produces PapR protein, which was then transported outside the cell. Several proteases cleave the ParR protein into small peptides, which again enter inside the cell, bind to PlcR protein, and finally turn on the virulence-secretion gene along with other gene related to stress and bacterial metabolism. Square boxes, oval boxes, solid, and dashed dotted lines indicate the genes, protein, direction of signaling pathway, and the products of the expressed genes, respectively. Small round circle indicates signaling molecules

virulence factors, including hemolysin $[47,48]$. The secretion of virulence factors in response to QS is illustrated in Figure 3. The transcription factor PlcR, along with AIP, regulates the virulence factor secretion genes in B. cereus [49]. The initiation of the QS signaling pathway begins with the expression of PapR gene. The translational product of the PapR gene is a 48 amino acid peptide (PapR), which is then transported outside the cell with the help of membrane transporter channel protein. The PapR peptide is then cleaved by the catalytic activity of protein B (the product of $\operatorname{NprB}$ gene) into four small peptides, such as 5, 7, 8, and 11 amino acids in length [50]. However, among these four peptides, only pentapeptide and heptapeptide are able to activate the PlcR gene, and thus considered as final AIP components [50]. Furthermore, Bouillaut et al. [51] reported that heptapeptide activation of $P l c R$ is dominant in in vivo condition. The final AIP then again enters in the cell through membrane channel protein, binds with PlcR protein, and stimulates the expression of several virulence factors secretion genes [52, 53]. Furthermore, Slamti and Lereclus [49] stated that pentapeptide starting with valine or methionine is unable to bind with PlcR protein. Recently, Huillet et al. [54] have characterized a new transcription factor 
PlcRa and have stated that heptapeptide-PlcRa complex was responsible for the regulation of cystine metabolism genes and oxidative stress-related genes during stationary phase of growth. On the other side, the product of $P l c R$ gene acts as an inhibitor of biofilm formation, but the detailed mechanism is still not clear [55]. However, it was detected that inactivation of $P l c R$ gene decreased the virulence factors secretion but was unable eliminate it completely [56]. Thus, it can be concluded that the PlcR transcription factor is not the ultimate key of virulence gene regulations in $B$. cereus. There are some other factors associated with virulence gene expression in $B$. cereus [57]. The available reports on QS circuit of $B$. cereus suggested that there is another pathway, through which virulence secretion genes are activated. To date, this pathway is not well-established and desperately needs more research attention.

\section{QS circuit in S. pneumoniae}

S. pneumoniae is a Gram-positive, facultative, anaerobic bacterium that causes pneumonia in humans. The development of biofilm in S. pneumonia is a QS-mediated process. Like other Gram-positive bacteria, S. pneumoniae also uses a 17 residue signal peptide called competence stimulating peptide or CSP [58]. In general, two types of gene regulation processes/pathways are observed in S. pneumoniae: early gene expression (regulated by ComE) and late gene expression (regulated by ComX). There are two sets of genes that are being expressed depending on time and expression of both these sets of genes resulted in competence development. The ComCDE operon plays a critical role in competence development and biofilm formation in $S$. pneumoniae [59]. The ComC gene encodes the immature CSP molecules in the cell, whereas the other two genes, ComD and ComE, act as transmembrane receptors for CSP molecules and response regulator system, respectively $[60,61]$. The conversion of the immature CSP molecules to an active one is done by other two gene products, ComA and ComB [61]. The transmembrane channel protein, ABC transporter actively transports the CSP molecules outside the cell, which then acts as an inducer molecule of the QS pathway. The binding of CSP to its receptor ComD phosphorylates it and transfers the phosphate group to ComE [62]. The activated ComE acts as a transcription factor for several genes, such as $\operatorname{ComAB}, \operatorname{ComC}$, and $C o m D E$ [59]. The ComE is also reported to be a transcription factor of the $\operatorname{Com} X$ gene that produces a sigma factor and ComW that is necessary for competence development [62]. Biofilm formation is a characteristic feature of pathogenic bacteria. In $S$. pneumoniae, biofilm formation is controlled by ComDE pathway. The phosphorylated ComE also induces the expression of several 
biofilm-associated genes, such as glucosyltransferase $\mathrm{B} / \mathrm{C} / \mathrm{D}$, glucan-binding protein $\mathrm{B}$, and fructosyltransferase [59]. The cumulative activities of these genes help in plaque formation. The detailed mechanism of QS-associated gene regulation in S. pneumoniae is presented in Figure 4.

\section{Future scope}

The unscientific use of antibiotics creates a selection pressure for the emergence of multidrug-resistant (MDR) bacteria [63]. Antibiotics are no longer

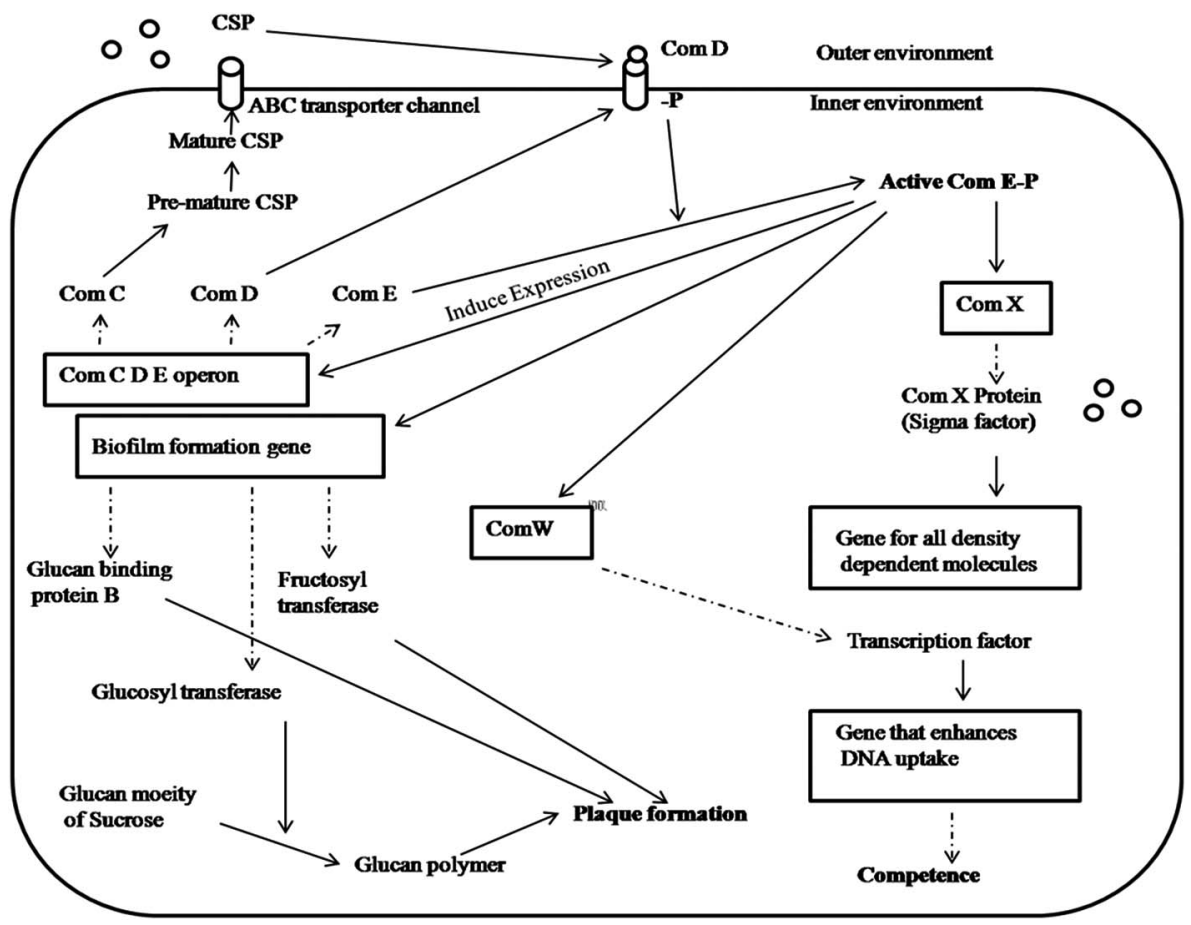

Figure 4. The drawing demonstrates the quorum-sensing system in Streptococcus pneumoniae. First, the ComCDE operon secretes competence stimulating peptides or CSP molecules, which are then transported outside the cell by ABC channel protein. Binding of CSP molecules to the outer surface of the membrane channel protein ComD activates it through the phosphorylation of the inner domain. Upon activation, ComD transfer its phosphate group to ComE, which modifies ComX and finally activates the density-dependent signaling pathway. Furthermore, the activated ComE also stimulates the expression of biofilm formation gene responsible for plaque development. Square boxes, solid, and dashed dotted lines indicate the genes, direction of signaling pathway, and the products of the expressed genes, respectively. Small round circle indicates signaling molecules 
the magic bullets they were once thought to be. QS inhibition might be an alternative approach for controlling pathogenic bacteria [4]. It is now wellestablished that the expression of virulence gene in pathogenic bacteria is mostly controlled by QS network, and thus it will be a novel target for antimicrobial therapy [7]. Several types of quorum-quenching molecules have been discovered or synthesized recently to inhibit the QS circuit in pathogenic bacteria [4]. Most of these QS analogue molecules mimic the AHL molecules and thus block the QS system in Gram-negative bacteria. However, there is very little information about the inhibition of QS system in Gram-positive bacteria using autoinducer-analogue molecules. Furthermore, antibody-based QS inhibition mechanism has also gained popularity in the recent years [7]. Several types of monoclonal antibodies have been reported for AHL-based QS circuit in bacteria [7]. However, few reports have been published regarding the antibody therapies in case of human diseases caused by pathogenic Gram-positive bacteria $[7,64]$. In addition, the detailed mechanism of antibody action is still not fully understood.

Furthermore, the QS circuits (AHL responsive transcriptional regulator and a cognate promoter) are also very useful indicators in recognizing pathogenic bacteria in clinical sectors. Extensive research should be conducted to explore the QS system in pathogenic bacteria, which would be helpful to treat human diseases in more effective manner. To date, the information about QS system is reported for cultured bacteria. It is well-established that most of the bacteria are uncultivable/cannot be cultured in laboratory condition [65]. The QS signal in metagenomic condition, especially in gut environment, is very much important in response to community establishment. The detailed understanding of QS circuit in animal gut might be a weapon in the treatment of metabolic disorders in future.

\section{Conclusions}

In the recent years, QS type of chemical communication in bacteria has received special attention. In this present review, we have summarized the QS circuit and their associated gene regulation in four Gram-positive bacteria, such as B. subtilis, S. aureus, B. cereus, and S. pneumoniae (Table II).

As environmental conditions often rapidly change, the coordinated behavior in bacteria is crucial for rapid response. The activation of a QS pathway is a cell density-dependent phenomenon, which helps bacteria to increase their own population and ultimately enhance the survival chances or to inhibit/kill the other competitive species. QS system also helps pathogenic bacteria to escape from the 
Table II. Comparative evaluation of QS network in four Gram-positive bacteria

\begin{tabular}{|c|c|c|c|}
\hline Bacterial species & QS circuit & Inducer molecules & Responses \\
\hline Bacillus subtilis & $\begin{array}{l}\text { ComP- } \\
\text { ComA }\end{array}$ & ComX, CSF & $\begin{array}{l}\text { Competence development and } \\
\text { sporulation }\end{array}$ \\
\hline $\begin{array}{l}\text { Staphylococcus } \\
\text { aureus }\end{array}$ & agr system & $\begin{array}{l}\text { Octapeptide autoinducing } \\
\text { molecule }\end{array}$ & Toxin secretion \\
\hline Bacillus cereus & PapR-PlcR & $\begin{array}{l}\text { Pentapeptide, } \\
\text { heptapeptide }\end{array}$ & Toxin secretion \\
\hline $\begin{array}{r}\text { Streptococcus } \\
\text { pneumoniae }\end{array}$ & $\begin{array}{l}\text { ComCDE } \\
\text { operon }\end{array}$ & 17 residue $\mathrm{CSP}$ & $\begin{array}{l}\text { Biofilm formation and competence } \\
\text { development }\end{array}$ \\
\hline
\end{tabular}

Note: QS: quorum sensing; CSF: competence stimulating factor; agr: accessory gene regulator; CSP: competence stimulating peptide.

host immune system. Majority of the research on QS have focused on the Gramnegative bacteria, as most of these are known/identified to be pathogens in humans and animals. Few species of Gram-positive bacteria are also considered as human pathogens, such as $S$. pneumoniae and B. cereus, and their pathogenicity-related QS system have been deeply investigated. In the present review, we have summarized the recent advancements in QS-signaling research in $S$. pneumoniae and B. cereus. During QS process in S. aureus, B. cereus, S. pneumoniae, and $B$. subtilis, the expression of several other genes has also been noticed, but their roles in QS phenomenon are still unknown.

The emergence of MDR bacteria is a big threat for human beings. In recent years, several reports have been published regarding the drug-resistant $S$. pneumoniae. The use of QS inhibition molecules might be an alternative way in the treatment of diseases caused by MDR bacteria. Furthermore, these QS inhibition molecules do not hamper the normal growth of the bacteria and thus will not create any selection pressure for the emergence of MDR bacteria. Thus, QS inhibition molecules could have longer functional shelf life than modern antibiotics in treating disease caused by pathogenic bacteria.

\section{Acknowledgement}

The authors are very much grateful to Department of Zoology, VisvaBharati University, India, for providing the necessary support and cooperation.

\section{Conflict of Interest}

The authors declare no conflict of interest. 


\section{References}

1. Engebrecht, J., Silverman, M.: Identification of genes and gene products necessary for bacterial bioluminescence. Proc Natl Acad Sci U S A 81, 4154-4158 (1984).

2. Nealson, K. H., Hastings, J. W.: Bacterial bioluminescence: Its control and ecological significance. Microbiol Rev 43, 496-518 (1997).

3. Antunes, L. C. M., Ferreira, R. B. R., Buckner, M. M. C., Finlay, B. B.: Quorum sensing in bacterial virulence. Microbiology 156, 2271-2282 (2010).

4. Banerjee, G., Ray, A. K.: The talking language in some major Gram negative bacteria. Arch Microbiol 198, 489-499 (2016).

5. Moghaddam, M. M., Khodi, S., Mirhosseini, A.: Quorum sensing in bacteria and a glance on Pseudomonas aeruginosa. Clin Microbial 3, 156 (2014).

6. Deep, A., Chaudhary, U., Gupta, V.: Quorum sensing and bacterial pathogenicity: From molecules to disease. J Lab Physicians 3, 4-11 (2011).

7. LaSarre, B., Federle, M. J.: Exploiting quorum sensing to confuse bacterial pathogens. Microbiol Mol Biol Rev 77, 73-111 (2013).

8. Rutherford, S. T., Bassler, B. L.: Bacterial quorum sensing: Its role in virulence and possibilities for its control. Cold Spring Harb Perspect Med 2, a012427 (2012).

9. Goo, E., An, J. H., Kang, Y., Hwang, I.: Control of bacterial metabolism by quorum sensing. Trends Microbiol 23, 567-576 (2015).

10. Miller, M. B., Bassler, B. L.: Quorum sensing in bacteria. Annu Rev Microbiol 55, 165-199 (2011).

11. Hamoen, L. W., Venema, G., Kuipers, O. P.: Controlling competence in Bacillus subtilis: Shared use of regulators. Microbiology 149, 9-17 (2003).

12. Mashburn-Warren, L., Morrison, D. A., Federle, M. J.: A novel double-tryptophan peptide pheromone controls competence in Streptococcus spp. via an Rgg regulator. Mol Microbiol 78, 589-606 (2010).

13. Williams, P., Camara, M.: Quorum sensing and environmental adaptation in Pseudomonas aeruginosa: A tale of regulatory networks and multifunctional signal molecules. Curr Opin Microbiol 12, 182-191 (2009).

14. Kuipers, O. P., de Ruyter, P. G. G. A., Kleerebezem, M., de Vos, W. M.: Quorum sensingcontrolled gene expression in lactic acid bacteria. J Biotechnol 64, 15-21 (1998).

15. Carter, G. P., Purdy, D., Williams, P., Minton, N. P.: Quorum sensing in Clostridium difficile: Analysis of a LuxS-type signaling system. J Med Microbiol 54, 119-127 (2005).

16. Garmyn, D., Gal, L., Lemaitre, J. P., Hartmann, A., Piveteau, P.: Communication and autoinduction in the species Listeria monocytogenes. Commun Integr Biol 2, 371-374 (2009).

17. Liu, M., Li, A.: Quorum sensing involved in the regulation of secondary metabolism in Streptomyces - A review. Wei Sheng Wu Xue Bao 51, 571-578 (2011).

18. Nakayama, J., Yokohata, R., Sato, M., Suzuki, T., Matsufuji, T., Nishiguchi, K., Kawai, T., Yamanaka, Y., Nagata, K., Tanokura, M., Sonomoto, K.: Development of a peptide antagonist against fsr quorum sensing of Enterococcus faecalis. ACS Chem Biol 8, 804-811 (2013).

19. Maldonado, A., Jiménez-Díaz, R., Ruiz-Barba, J. L.: Induction of plantaricin production in Lactobacillus plantarum NC8 after coculture with specific Gram-positive bacteria is mediated by an autoinduction mechanism. J Bacteriol 186, 1556-1564 (2004). 
20. Rizzello, C. G., Filannino, P., Cagno, R. D., Calasso, M., Gobbetti, M.: Quorum-sensing regulation of constitutive plantaricin by Lactobacillus plantarum strains under a model system of vegetables and fruits. Appl Environ Microbiol 80, 777-787 (2014).

21. Polkade, A. V., Mantri, S. S., Patwekar, U. J., Jangid, K.: Quorum sensing: An underexplored phenomenon in the phylum Actinobacteria. Front Microbiol 7, 131 (2016).

22. Miyake, K., Kuzuyama, T., Horinouchi, S., Beppu, T.: The A-factor-binding protein of Streptomyces griseus negatively control streptomycin production and sporulation. J Bacteriol 172, 3003-3008 (1990).

23. Jimenez, J. C., Federle, M. J.: Quorum sensing in group A. Streptococcus. Front Cell Infect Microbiol 4, 127 (2014).

24. Rocha-Estrada, J., Aceves-Diez, A. E., Guarneros, G., de la Torre, M.: The RNPP family of quorum-sensing proteins in Gram-positive bacteria. Appl Microbiol Biotechnol 87, 913-923 (2010).

25. Bassler, B. L.: How bacteria talk to each other: Regulation of gene expression by quorum sensing. Curr Opin Microbiol 2, 582-587 (1999).

26. Ansaldi, M., Marolt, D., Stebe, T., Mandic-Mulec, I., Dubnau, D.: Specific activation of the Bacillus quorum-sensing systems by isoprenylated pheromone variants. Mol Microbiol 44, 1561-1573 (2002).

27. Mayville, P., Ji, G., Beavis, R., Yang, H., Goger, M., Novick, R. P., Muir, T. W.: Structureactivity analysis of synthetic autoinducing thiolactone peptides from Staphylococcus aureus responsible for virulence. Proc Natl Acad Sci U S A 96, 1218-1223 (1999).

28. Bendori, S. O., Pollak, S., Hizi, D., Eldar, A.: The RapP-PhrP quorum-sensing system of Bacillus subtilis strain NCIB3610 affects biofilm formation through multiple targets, due to an atypical signal-insensitive allele of RapP. J Bacteriol 3, 592-602 (2015).

29. Grossman, A. D.: Genetic networks controlling the initiation of sporulation and the development of genetic competence in Bacillus subtilis. Annu Rev Gen 29, 477-508 (1995).

30. Zafra, O., Lamprecht-Grandío, M., de Figueras, C. G., González-Pastor, J. E.: Extracellular DNA release by undomesticated Bacillus subtilis is regulated by early competence. PLoS One 7, e48716 (2012).

31. Solomon, J., Magnuson, R., Srivastava, A., Grossman, A. D.: Convergent sensing pathways mediate response to two extracellular competence factors in Bacillus subtilis. Genes Dev 9 , 547-558 (1995).

32. Solomon, J. M., Lazazzera, B. A., Grossman, A. D.: Purification and characterization of an extracellular peptide factor that affects two developmental pathways in Bacillus subtilis. Genes Dev 10, 2014-2024 (1996).

33. Weinrauch, Y., Penchev, R., Dubnau, E., Smith, I., Dubnau, D.: A Bacillus subtilis regulatory gene product for genetic competence and sporulation resembles sensor protein members of the bacterial two-component signal-transduction systems. Genes Dev 4, 860-872 (1990).

34. Dogsa, I., Choudhary, K. S., Marsetic, Z., Hudaiberdiev, S., Vera, R., Pongor, S., Mandic-Mulec, I.: ComQXPA quorum sensing systems may not be unique to Bacillus subtilis: A census in prokaryotic genomes. PLoS One 9, e96122 (2014).

35. Dubnau, D., Turgay, K.: The regulation of competence in Bacillus subtilis and its relation to stress response. In Storz, G., Hengge-Aromis, R. (eds): Bacterial stress responses. American Society for Microbiology, Washington, DC, 2000, pp. 249-260. 
36. van Sinderen, D., ten Berge, A., Hayema, B. J., Hamoen, L., Venema, G.: Molecular cloning and sequence of comK, a gene required for genetic competence in Bacillus subtilis. Mol Microbiol 11, 695-703 (1994).

37. Brackman, G., Breyne, K., De Rycke, R., Vermote, A., Van Nieuwerburgh, F., Meyer, E., Van Calenbergh, S., Coenye, T.: The quarum sensing inhibitor hamamelitannin increases antibiotic susceptibility of Staphylococcus aureus biofilm by affecting peptidoglycan biosynthesis and eDNA release. Sci Rep 6, 20321 (2010).

38. Koch, G., Yepes, A., Förstner, K. U., Wermser, C., Stengel, S. T., Modamio, J., Ohlsen, K., Foster, K. R., Lopez, D.: Evolution of resistance to a Last-Resort antibiotic in Staphylococcus aureus via bacterial competition. Cell 158, 1060-1071 (2014).

39. Novick, R. P.: Regulation of pathogenicity in Staphylococcus aureus by a peptide-based density-sensing system. In Dunny, G. M., Winans, S. C. (eds): Cell-Cell Signaling in Bacteria. ASM Press, Washington, 1999, pp. 129-146.

40. Sifri, C. S.: Quorum sensing: Bacteria talk sense. Clin Infect Dis 47, 1070-1076 (2008).

41. Ji, G., Beavis, R., Novick, R. P.: Bacterial interference caused by autoinducing peptide variants. Science 276, 2027-2030 (1997).

42. Kirchdoerfer, R. N., Garner, A. L., Flack, C. E., Mee, J. M., Horswill, A. R., Janda, K. D., Kaufmann, G. F., Wilson, I. A.: Structural basis for ligand reorganization and discrimination of a quorum-quenching antibody. J Biol Chem 286, 17351-17358 (2011).

43. Queck, S. Y., Jameson-Lee, M., Villaruz, A. E., Bach, T. H., Khan, B. A., Sturdevant, D. E., Ricklefs, S. M., Li, M., Otto, M.: RNAIII-independent target gene control by the agr quorum- sensing system: Insight into the evolution of virulence regulation in Staphylococcus aureus. Mol Cell 32, 150-158 (2008).

44. Vuong, C., Saenz, H. L., Gotz, F., Otto, M.: Impact of the agr quorum-sensing system on adherence to polystyrene in Staphylococcus aureus. J Infect Dis 182, 1688-1693 (2000).

45. Boles, B. R., Horswill, A. R.: Agr-mediated dispersal of Staphylococcus aureus biofilms. PLoS Pathog 4, e1000052 (2008).

46. Oogai, Y., Matsuo, M., Hashimoto, M., Kato, F., Sugai, M., Komatsuzawa, H.: Expression of virulence factors by Staphylococcus aureus grown in serum. Appl Environ Microbiol 77, 8097-8105 (2012).

47. Bottone, E. J.: Bacillus cereus, a volatile human pathogen. Clin Microbiol Rev 23, 382-398 (2010).

48. Brézillon, C., Haustant, M., Dupke, S., Corre, J. P., Lander, A., Franz, T., Monot, M., Couture-Tosi, E., Jouvion, G., Leendertz, F. H., Grunow, R., Mock, M. E., Klee, S. R., Goossens, P. L.: Capsules, toxins and AtxA as virulence factors of emerging Bacillus cereus biovar anthracis. PLoS Negl Trop Dis 9, e0003455 (2015).

49. Slamti, L., Lereclus, D.: Specificity and polymorphism of the PlcR-PapR quorum-sensing system in the Bacillus cereus group. J Bacteriol 187, 1182-1187 (2005).

50. Pomerantsev, A. P., Pomerantseva, O. M., Camp, A. S., Mukkamala, R., Goldman, S., Leppla, S. H.: PapR peptide maturation: Role of the NprB protease in Bacillus cereus 569 PlcR/PapR global gene regulation. FEMS Immunol Med Microbiol 55, 361-377 (2009).

51. Bouillaut, L., Perchat, S., Arold, S., Zorrilla, S., Slamti, L., Henry, C., Gohar, M., Declerck, N., Lereclus, D.: Molecular basis for group-specific activation of the virulence regulator PlcR by PapR heptapeptides. Nucleic Acids Res 36, 3791-3801 (2008). 
52. Gominet, M., Slamti, L., Gilois, N., Rose, M., Lereclus, D.: Oligopeptide permease is required for expression of the Bacillus thuringiensis plcR regulon and for virulence. Mol Microbiol 40, 963-975 (2001).

53. Declerck, N., Bouillaut, L., Chaix, D., Rugani, N., Slamti, L., Hoh, F., Lereclus, D., Arold, S. T.: Structure of PlcR: Insights into virulence regulation and evolution of quorum sensing in Gram-positive bacteria. Proc Natl Acad Sci U S A 104, 18490-18495 (2007).

54. Huillet, E., Tempelaars, M. H., Andre'-Leroux, G., Wanapaisan, P., Bridoux, L., Makhzami, S., Panbangred, W., Martin-Verstraete, I., Abee, T., Lereclus, D.: PlcRa, a new quorum-sensing regulator from Bacillus cereus, plays a role in oxidative stress responses and cysteine metabolism in stationary phase. PLoS One 7, e51047 (2012).

55. Hsueh, Y. H., Somers, E. B., Lereclus, D., Leewong, A. C.: Biofilm formation by Bacillus cereus is influenced by PlcR, a pleiotropic regulator. Appl Environ Microbiol 72, 50895092 (2006).

56. Callegan, M. C., Kane, S. T., Cochran, D. C., Gilmore, M. S., Gominet, M., Lereclus, D.: Relationship of plcR-regulated factors to Bacillus endophthalmitis virulence. Infect Immun 71, 3116-3124 (2003).

57. Frenzel, E., Doll, V., Pauthner, M., Lucking, G., Scherer, S., Ehling-Schulz, M.: Cod Yorchestrates the expression of virulence determinants in emetic Bacillus cereus by impacting key regulatory circuits. Mol Microbiol 85, 67-88 (2012).

58. Havarstein, L. S., Coomaraswamy, G., Morrison, D. A.: An unmodified heptadecapeptide pheromone induces competence for genetic transformation in Streptococcus pneumonia. Proc Natl Acad Sci U S A 1995, 11140-11144 (1995).

59. Suntharalingam, P., Cvitkovitch, D. G.: Quorum sensing in streptococcal biofilm formation. Trends Microbiol 13, 3-6 (2005).

60. Claverys, J. P., Havarstein, L. S.: Extracellular peptide control of competence for genetic transformation in Streptococcus pneumonia. Front Biosci 7, 1798-1814 (2002).

61. Waters, C. M., Bassler, B. L.: Quorum sensing: Cell-to-cell communication in bacteria. Annu Rev Cell Dev Biol 21, 319-346 (2005).

62. Aspiras, M. B., Ellen, R. P., Cvitkovitch, D. G.: ComX activity of Streptococcus mutans growing in biofilms. FEMS Microbiol Lett 238, 167-174 (2004).

63. Ventola, C. L.: The antibiotic resistance crisis: Part 1: Causes and threats. PT 40, 277-283 (2015).

64. Park, J., Jagasia, R., Kaufmann, G. F., Mathison, J. C., Ruiz, D. I., Moss, J. A., Meijler, M. M., Ulevitch, R. J., Janda, K. D.: Infection control by antibody disruption of bacterial quorum sensing signaling. Chem Biol 14, 1119-1127 (2007).

65. Stewart, E. J.: Growing unculturable bacteria. J Bacteriol 194, 4151-4160 (2012). 